\title{
THE EXPANSOR SECUNDARIORUM MUSCLE, WITH SPECIAL REFERENCE TO PASSERINE BIRDS
}

\author{
ANDREW J. BERGER \\ Department of Anatomy, University of Michigan \\ Medical School, Ann Arbor
}

NINE FIGURES

Eighty years ago, Alfred H. Garrod (1876: 193-194) described and named a small muscle, whose fleshy belly, located at the bend of the elbow, inserted on the bases of several of the proximal secondaries, and whose tendon of origin had a variable pattern of attachment to ligaments and bones of the pectoral girdle and sternum. This muscle he called the expansor secundariorum. In studying the myology of certain non-passerine birds (Coua caerulea, '53: 59 and fig. 1; Geococcyx, Crotophaga, and Coccyzus, '54: 17-18; Chrysococcyx cupreus, '55: 590; Polihierax semitorquatus, '56), I found a second (humeral) attachment for this muscle. So far as I know, the double origin for this muscle mass had not been described previously.

Garrod felt that M. expansor secundariorum was useful as a taxonomic character and he tabulated families of birds in which he had or had not found it (1876: 199). Among Anomalogonatous birds (those lacking the ambiens muscle), he found it only in the Coraciidae. Forbes later (1885: 346) added that the expansor secundariorum muscle is also present in Leptosoma, the Meropidae, Galbulidae, and, possibly, in the Buc- 
conidae, but that it is absent in all the other families of the Anomalogonatae, including the Passeriformes. Shufeldt (1890: 78) did not find it in the Raven (Corvus corax sinuatus). Gadow and Selenka (1891: 260; 1893: 261), Newton (1896: 608), Beddard (1898: 172), Ridgway ('01: 13), Bannerman ('36:2), and Witherby et al. ('43: vol. 1, p. 7) all stated that this muscle is absent in passerine birds. Swinebroad ('54) did not describe it in Passer domesticus and several genera of fringillids.

I was surprised some time ago, therefore, when I saw what I believed to be this muscle in a specimen of Tanagra affinis, though I found only a humeral attachment in the specimen I had for dissection. Burt (' $30: 497$ and fig. 15) had deseribed and illustrated such a muscle, having only a humeral attachment, in Dryocopus pileatus picinus. Because of the presumed close relationship between the Pico-Passeres, this finding seemed quite logical. I was not surprised, therefore, in correspondence with Dr. George E. Hudson, when he stated that this muscle was present in all members of the Corvidae which he had dissected at that time (letter, December 6, 1951; see also Berger, '53: 59). To the best of my knowledge, the first published description in English of M. expansor secundariorum in a passerine bird is that of Hudson and Lanzillotti ('55: 23), though they did not comment on the significance of their findings. Based on my studies, I believe that this muscle is to be found in all passerine birds. This paper reports my findings.

\section{MATERIALS AND METHODS}

Gross dissections, with a binocular microscope (magnification $\times 10$ and $\times 20$ ), were made on specimens of all of the species listed below. Microscopic sections were made of certain muscles from individuals of those species marked with an asterisk; I did not, however, examine microscopically the expansor secundariorum muscle from all species of passerines. 
Colymbidae

* Podilymbus podiceps

Falconidae

Polihierax semitorquatus

Phasianidae

* Colinus virginianus

Gruidae

* Grus canadensis tabida

Rallidae

* Gallinula chloropus

Columbidae

* Columba livia

Musophagidae

Turacus donaldsoni

Cueulidae

* Geococevx califormianus

* Crotophaga sulcirostris

* Morococeyx erythropygus

Troehilidae

* Archilochus colubris

Bucerotidae

* Aceros undulatus

Picidae

* Colaptes auratus luteus

Eurylaimidae

* Smithornis rufolateralis

Furnariidae

Synallaxis albilora

Formicariidae

Taraba m. major

* Hypocnemis flavescens

Cotingidae

Lathria cinerea

Tyrannidae

Tyrannus tyrannus

* Empidonax minimus

Contopus virens

Alaudidae Eremophila alpestris

Hirundinidae

Stelgidopteryx ruficollis

* Progne subis

Corvidae

* Cyanoeitta cristata

Paradisaeidae

Paradisaea rubra
Paridae

Parus bicolor

Sittidae

Sitta carolinensis

Troglodytidae

Troglodytes aedon

Mimidae

* Dumetella carolinensis

* Toxostoma rufum

Turdidae

* Turdus migratorius

Sylviidae

Polioptila caerulea

* Regulus satrapa

Bombycillidae

* Bombycilla cedrorum

Sturridae

* Sturnus vulgaris

Vireonidae

Vireo flavifrons

Vireo olivaceous

* Vireo gilvus

Parulidae

Dendroica petechia

* Dendroica cerulea

* Dendroica pinus Seiurus aurocapillus

* Oporornis agilis

Ploceidae

* Passer domesticus Quelea quelea

Icteridae

* Sturnella magna Agelaius phoeniceus

* Molothrus a. ater

Thraupidae

- Piranga olivacea Tanagra affinis

Fringillidae

* Riclimondena cardinalis

- Spinus tristis

* Pipilo erythrophthalmus Juneo hyemalis Spizella pusilla Zonotrichia albicollis Melospiza melodia

* Plectrophenax nivalis

Some of the muscles were imbedded in gelatin and then sectioned with a freezing microtome; others were imbedded in paraffin and sectioned in the usual manner. Gelatin sections were stained either with Ehrlich's acid hematoxylin or with Mallory's triple stain. Paraffin sections were stained rou- 
tinely with Ehrlich's acid hematoxylin and eosin and with Masson's triple stain; other sections were treated with iron hematoxylin (see Bensley and Bensley, '38: 78).

In order to study and measure muscle fibers, I modified Huber's ('16) technique for isolating individual muscle fibers. For this purpose, the muscles were macerated either with $3 \%$ or $6 \%$ formic acid ; fascicles were then teased apart manually and stained with Ehrlich's acid hematoxylin for 10 to 60 minutes. After a wash in distilled water and ammonia water, the muscle fibers were mounted in glycerol gelatin. This method has the advantage that the nuclei and chromatin are distinctly seen, whereas with Huber's method, the nuclei are not evident ('16: 153). Other macerated preparations were stained with iron hematoxylin. Muscles from freshlykilled birds were treated with a modified Ranvier gold chloride nerve stain (see Lillie, '48: 241).

I am deeply indebted to my colleague Dr. Wilbur B. Quay for his generous and effective guidance in conducting the histological portion of the study. Most of the passerine species I collected myself; some specimens were obtained from the University of Michigan Museum of Zoology. The specimen of Tanagra affinis was collected in Mexico on January 4, 1951, by Mrs. Jean Graber and was presented to me by Dr. George M. Sutton, who also collected for me the Crotophaga sulcirostris. For other specimens I am further indebted to: Mr. Wallace Grange of Babcock, Wisconsin, Grus canadensis; Mr. John G. Williams of the Coryndon Museum, Nairobi, Polihierax semitorquatus; Dr. E. P. Edwards, Morococcyx erythropygus; Dr. Dean Amadon, Smithornis rufolateralis; Dr. Herbert Friedmann, Turacus donaldsoni, Synallaxis albilora, Taraba major, Hypocnemis flavescens, and Lathria cinerea; Mr. Keith Kreag of the Detroit Zoological Park, Aceros undulatus and Paradisaea rubra; Dr. John T. Emlen, Quelea quelea. 
GROSS ANATOMY

The classical description of $M$. expansor secundariorum (Garrod, 1876:193) is well illustrated by the condition found in the Sandhill Crane (Grus canadensis tabida). In this crane (fig. 1), I found a well-developed triangular-shaped belly

\section{ABBREVIATIONS}

Ane., M. anconaeus coracoideus

Cor., coracoid

Dor. scap., M. dorsalis scapulae

Exp., M. expansor secundariorum

F, feather

Flex, e. u., M. flexor carpi ulnaris (humero-ulnar pulley not shown)

Flex. dig., tendon of origin of $M$. flexor digitorum sublimus

$\mathbf{H}$, humerus
Met., metapatagial skin fold

Pect., small part of $M$. pectoralis

Pro. brev., M. pronator brevis

Pro. long., M. Pronator longus

SKM, skeletal musele

SM, smooth muscle

St., sternum

T. hum., M. humerotriceps

T. scap., M. scapulotriceps

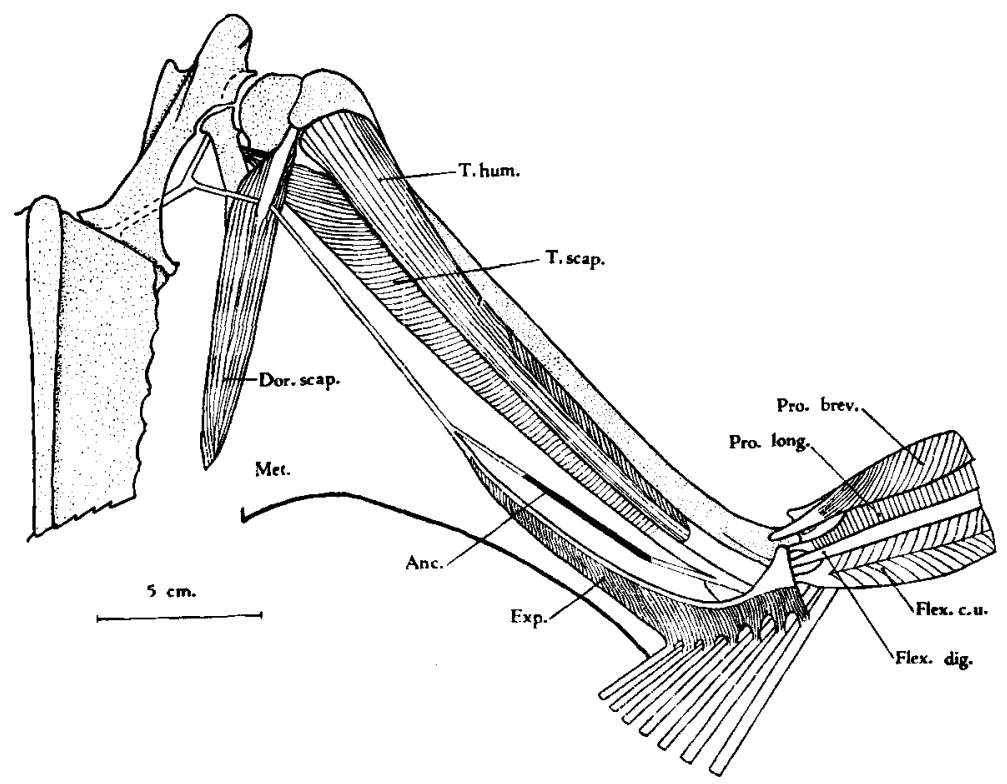

Fig. 1 Grus canadensis tabida. Ventral view of proximal region of wing to show the relationships of $\mathrm{Mm}$. anconaeus coracoideus and expansor secundariorum. The distal end of the humerus is distorted in order to show the triceps tendon and the origin of forearm muscles. Mm. pectoralis, supracoracoideus, and coracobrachialis posterior have been removed. Not shown is the fascial extension of the flexor digitorum sublimus tendon, which invests the superficial surface of $M$. flexor carpi ulnaris. 
about $10 \mathrm{~cm}$ long and $3 \mathrm{~cm}$ wide at its attachment to several secondaries near the elbow; the belly extends over a third the way up the arm, where some fasciculi are attached to the skin forming the dorsal layer of the metapatagium (for metapatagium, see Gadow and Selenka, 1891: 258). The strong tendon pierces the lowermost semitendinous fibers (which function as a pulley) of $\mathrm{M}$. dorsalis scapulae, about $2 \mathrm{~cm}$ from the insertion of that muscle, and then bifurcates. The larger ventral branch of the tendon has its major attachment to the medial corner of the sternocoracoidal process of the sternum; the smaller, dorsal branch passes dorsomesiad to attach to the ventral edge of the scapula, near its articulation with the procoracoid. There is also a tendinous origin from the distal end of the humerus. Fürbringer ('02:572) called the tendon or ligament extending from the scapula to the sternum or coracoid the "sterno-coraco-scapulare internum" ligament; Newton (1896: 608) called it simply the "sternoscapular ligament." These authors considered that the expansor secundariorum tendon took its origin from this "ligament." This is a question of interpretation.

In Gallinula chloropus the expansor secundariorum muscle is similar to that in the Sandhill Crane, but certain differences exist. The dorsal branch of the main tendon passes upward between Mm. subscapularis (internal head) and subcoracoideus (scapular head) to attach to a tubercle on the dorsomedial, rather than the ventral, edge of the scapula. In addition, located deep to the main belly at the elbow, there is a second belly which arises from the distal end of the humerus and from the humero-ulnar pulley. This belly inserts on the same proximal secondaries as does the main muscle.

In the Rock Dove (Columba livia) the long, or scapular, tendon of this muscle arises from the dorsomedial edge of the scapula, where the tendon is partly fused with the fascia covering $M$. subscapularis (fig. 2). As it descends through the axilla, the tendon is intimately associated with the axillary and vascular fasciae, but $I$ could trace no distinct tendon to the sternum or the coracoid. At the inferior margin of $\mathrm{M}$. 
dorsalis scapulae, a second, short tendon, arising from the fascial envelope of the distal portion of that muscle, reinforces the main tendon. The fleshy belly arises from the main tendon near the junction of the middle and distal thirds of the humerus. The belly, about $2 \mathrm{~cm}$ long, inserts on the bases of the proximal 5 secondaries and their ventral coverts. Near the area of insertion, the tendon fans out into an aponeurosis on the deep surface of the belly; a flat tendon, arising

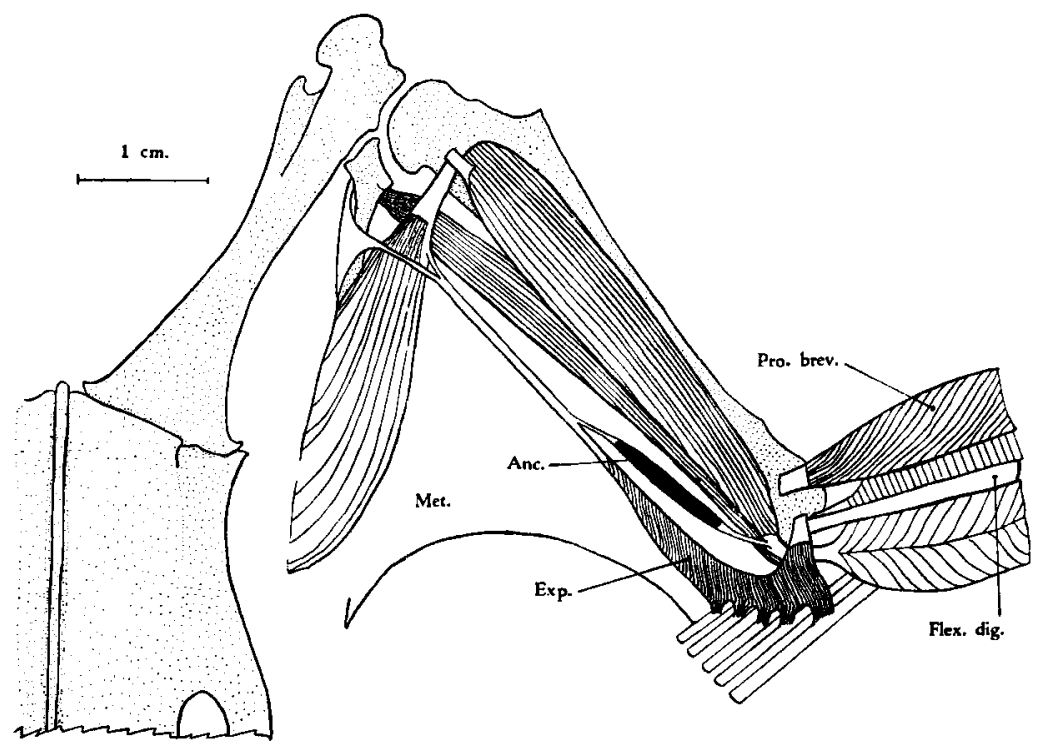

Fig. 2 Columba livia. Ventral view of certain muscles in the proximal region of the wing.

from the distal end of the humerus, fuses with this aponeurosis and gives origin to fleshy fasciculi. Other fleshy fibers arise directly from the humero-ulnar pulley; these fibers form the deepest part of the belly and insert on the 10th secondary. The Rock Dove differs from the Sandhill Crane in that the tendinous attachment to the sternum is absent and in that the humeral origin is more complicated. Hudson and Lanzillotti ('55: 23-24 and figs. 33, 34, and 35) illustrated, but did not describe completely, this muscle in Dendragapus obscurus 
and Falco mexicanus, but they did not illustrate it in Columba fasciata, where it almost certainly is present. The Rock Dove (4 specimens) and the Sandhill Crane differ from the other genera dissected for this paper in that, a short distance proximal to the origin of the main belly described above, a second fleshy band arises from the scapular tendon and passes distad toward the elbow, where a second tendon is formed. This tendon fuses with the tendon of M. scapulotriceps in the Sandhill Crane; in the Rock Dove, it fuses primarily with the distal end of M. humerotriceps near its insertion on the olecranon process of the ulna (see pages 153 and 159).

In certain other non-passerine genera (e.g., Geococcyx californianus, Coua caerulea, Turacus donaldsoni, Polihierax semitorquatus), the muscle arises, in part, by a broad aponeurosis from the dorsomedial edge of the scapula; this aponeurosis tends to fuse with the fascia covering the subscapularis muscle; there is no attachment to M. dorsalis scapulae. Distally, the tendon is attached either to the proximal end of the main belly or to a separate fleshy slip (see Berger, ' $53: 59$; ' 54 : 17), which extends proximad through the tricipital groove of the humerus. In all cases, however, there is also a secondary, stout, flat tendon of origin from the distal end of the humerus. The fleshy belly fans out and inserts on several of the proximal secondaries (also on several distal tertials in Geococcyx).

In Colinus virginianus (fig. 3), also, two different muscles insert on the proximal secondaries, the two muscles approaching each other almost at a right angle. A long, rounded belly arises primarily from a strong tendon whose proximal attachment is to the investing fascial envelope of $\mathrm{M}$. dorsalis scapulae, near the insertion of that muscle. The "ciconine" tendon or sternoscapular ligament (of Newton), extending from the scapula to the sternum, is absent, and I could not trace any extension of the tendon proximal to its attachment to the dorsalis scapulae muscle. In the two specimens I dissected, the round belly has a second tendinous origin; this is a thin fascial band, which seems to be derived solely from the lateral margin, near the insertion, of M. pectoralis. The 
thin tendon passes distad in the metapatagium and fuses with the main tendon (derived from M. dorsalis scapulae). This belly inserts on the proximal 4 secondaries, superficial to the insertion of the humeral belly. The second, triangularshaped, belly arises by a flat tendon from the distal end of the humerus and inserts on the bases of the 6 proximal secondaries.

I could not find a discrete tendon extending into the axilla in either of two specimens of Podilymbus podiceps. In this

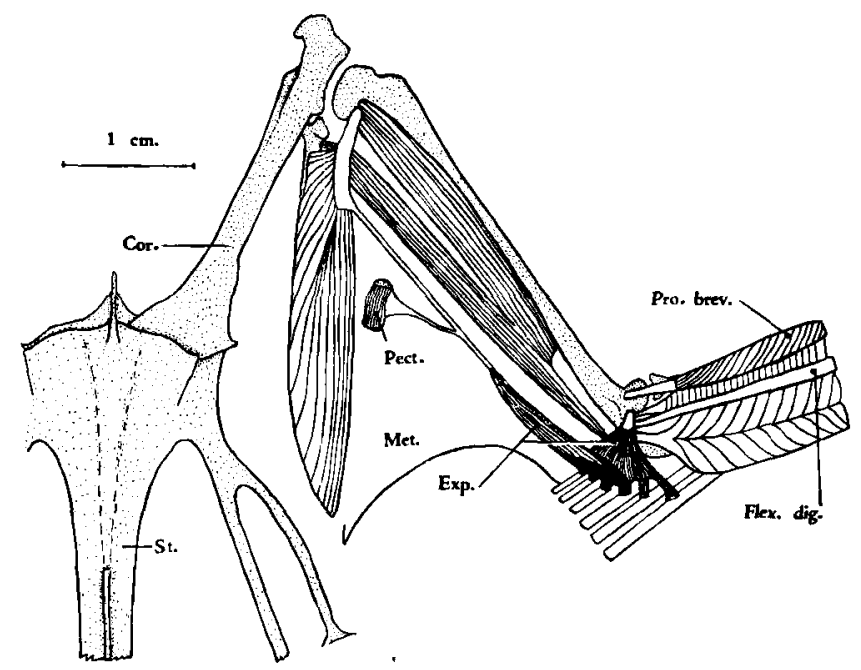

Fig. 3 Colinus virginianus. Ventral view of ecrtain muscles in the proximal region of the wing.

grebe, there is a tendinous origin only from the distal end of the humerus. Part of the belly inserts on the proximal secondaries. Other fleshy fibers extend upward around the elbow and about a third the distance up the arm, where the belly gives way to fibrous strands, which attach to the bases of feathers and become indistinguishable from the connective tissue of the metapatagium.

M. expansor secundariorum is well developed in Aceros undulatus and it exhibits certain peculiar features. The scapular tendon is absent. The belly arises by a flat, tendinous 
band from the distal end of the humerus. It inserts by wide tendinous bands on the calami of secondaries 11,12,13, and 14 , and by fleshy fibers on secondaries 15 and 16 , with an additional fleshy slip inserting on one of the small distal tertials. About one-third of the belly extends proximad through the tricipital groove of the humerus. This belly has a broad attachment, by means of a wide aponeurosis, to the fibrous tendon of M. serratus superficialis metapatagialis. From the apex of the belly, a small, but discrete and strong, tendon runs proximad in the metapatagium. About midlength of the arm, this tendon breaks up into multiple fibrous strands, which attach to the bases of feathers in the posterior axillary region (see Burt, '29: fig. 2). I know of no other genus in which there is a tendinous connection between this feather tract and the expansor secundariorum muscle. There also are tendinous connections with the fascia covering the inferior border of M. dorsalis scapulae.

One additional reference to the structure of the expansor secundariorum muscle in non-passerine birds is desirable. Forbes (1885: 394) described this muscle in Oceanites, in which genus the main tendon arises from the surface of M. pectoralis and a second tendon arises from the most posterior feathers of the humeral feather tract. In effect, there is a $\mathrm{Y}$-shaped tendon of origin for the muscle (see Forbes, 1885, pl. 17); the fleshy belly inserts on the proximal secondaries. Forbes stated that he knew of no other bird in which the expansor secundariorum muscle is attached to $\mathrm{M}$. pectoralis nor any in which the tendon is connected to the scapular feathers (those of the humeral tract). Though the situation is not precisely comparable, see the discussion on the passerines below. Forbes did not describe M. serratus metapatagialis and it is possible that the tendon of that muscle in Oceanites has relationships similar to those found in passerine birds.

From what I have seen in passerine birds, the typical origin of the expansor secundariorum muscle seems to be almost exclusively from the humero-ulnar pulley, this being an indirect rather than a direct origin from the humerus. The 
belly fans out and inserts primarily on the ventral surface of the calamus of the inner or proximal three secondaries; there may be small slips extending to a 4th secondary or to the outermost tertial. In a specimen of Troglodytes aedon there was a double origin, from the humero-ulnar pulley and by a flat tendon from the distal end of the humerus. In Regulus satrapa this musele arises by a tendon from the distal end of the humerus; the tendon winds around the humero-ulnar pulley and is intimately associated with the humeral attachment of that pulley. In general, however, the origin in passerine birds seems to have migrated from the distal end of the humerus to the humero-ulnar pulley.

In none of the passerine genera did I find a long tendon extending proximad through the metapatagium and into the axilla to attach to ligaments or bones in that region, as is characteristic of many non-passerine birds. There is, however, a close relationship between $\mathrm{Mm}$. expansor secundariorum and serratus superficialis metapatagialis. The latter muscle arises from the lateral surface of one or more of the true ribs. The fleshy belly terminates in the region of the posterior margin of the humeral feather tract. At the latter point, the belly gives rise to a fibrous band, which extends toward the elbow a variable distance. In some species ( $E m$ pidonax minimus, Cyanocitta cristata, Vireo flavifrons, Seiurus aurocapillus, Agelaius phoeniceus, Spinus tristis, Spizella pusilla), this band fans out in the metapatagium and becomes indistinct before it reaches the elbow; the tendon, therefore, cannot be traced with certainty to the proximal region of the forearm. In other species (Taraba major, Lathria cinerea, Tyrannus tyrannus, Progne subis, Turdus migratorius, Bombycilla cedrorum, Vireo gilvus, Dendroica petechia, Quelea quelea, Sturnella magna, Molothrus ater, Junco hyemalis), the fibrous band gives way to a fine tendon, which I could trace to its termination either on the proximal surface of M. expansor secundariorum, or on the base of the innermost secondary (near the insertion of the muscle), or to its attachments on both of these structures. This tendon and its distal 
attachments exhibited the best development in Taraba major, Lathria cinerea, Molothrus ater (in an adult, but not in an immature specimen), Turdus migratorius, Bombycilla cedrorum, and Vireo gilvus.

How much individual variation there is in the extent and development of the metapatagial tendon I cannot say. It is clear from what has just been said, however, that within a given family the tendon may or may not reach the elbow as a discrete entity. It seems probable that such an extension is to be found well developed in some families of passerine birds. In fact, Leach ('14:7) described the serratus metapatagialis (= dermo-ulnaris) in the Bell-magpie (Strepera graculina) as follows: It passes directly into the post-patagium as a wide, fleshy, conspicuous muscle. It soon narrows to a strong tendon, which runs on to join the fascia overlying the end of the ulna about the elbow joint. Leach did not mention M. expansor secundariorum, but he may have been referring to it, in part, in his description of $M$. flexor carpi ulnaris when he said ('14:19) that a superficial fascia "with muscle fibres" about the elbow arises near the tendon of the lower part of this muscle. Helm (1884: 339, etc.) also described the elastic portion of the serratus metapatagialis ("Spanner der hintern Flughaut") insertion, though he did not mention that it could at times be traced to the elbow region. Shufeldt (1890: 13) commented that the metapatagialis tendon extends to the elbow in the Raven.

Because of their taxonomic position, I was especially anxious to examine the Broadbills (Family Eurylaimidae), even though several excellent papers on the anatomy of this family have been published (Garrod, 1881: 368; Forbes, 1885: 138; Pycraft, '05; Lowe, '24 and '31). Lowe, in his discussion of Smithornis rufolateralis ('24), did not mention the expansor secundariorum muscle and he stated ('31: 451) that it was not present in Pseudocalyptomena graueri. I had one specimen of Smithornis rufolateralis for study. In this bird, the expansor secundariorum muscle arises by a tendon from the humero-ulnar pulley; it inserts on the proximal three sec- 
ondaries. There also is a very small ( $1 \mathrm{~mm}$ long), fleshy slip extending proximad from the main belly. From this slip, a fine, hair-like tendon passes upward through the metapatagium and ends on the fibrous band of M. serratus superficialis metapatagialis. The latter muscle is well developed. From the area of insertion of the fleshy belly at the caudal end of the humeral feather tract, one can trace a fibrous band distad. Near the elbow, this band changes into a wide, but delicate, aponeurosis, which attaches to the expansor secundariorum muscle near its ligamentous origin from the humeroulnar pulley. The muscle and its tendon, therefore, have a typical passerine configuration.

From what has been reported above, we can say that between the passerine and the non-passerine condition there appears to be a clear-cut difference in the relationships of M. expansor secundariorum. What, then, should one expect to find in the Picidae? In Dryocopus, Burt ('30: 497 and fig. 15) found a humeral origin, but did not mention any other tendon. In Colaptes auratus luteus, I found (as did Burt) that $M$. serratus metapatagialis gives rise to a prominent fibrous band, which passes distad in the metapatagium changing into a discrete tendon. This tendon is continuous with a proximally-directed, fleshy slip of M. expansor secundariorum; the humeral origin also is present. In short, one finds the same general pattern in the passerines as in the Yellowshafted Flicker, except that in the latter, both the expansor secundariorum muscle and its tendinous connection with the serratus metapatagialis muscle exhibit a better development. Buri ('00: 416) also mentioned the extension to the elbow of the metapatagialis tendon in Picus viridis, and he further reported ('00:546) the presence of the expansor secundariorum muscle in Picus viridis, Dendrocopus major, and Jynx torquilla.

Buri's excellent, but little used, paper ('00), however, indicates that there is not a uniform difference in configuration of the expansor secundariorum muscle between the PicoPasserines and the remaining non-passerines. Buri described 
and illustrated this muscle in Caprimulgus, Apus (="Micropus"), and Colius, and in each instance he showed a humeral origin, but gave no indication of the presence of a long tendon arising from bones of the pectoral girdle. Furthermore, I found the long tendon to be absent in Podilymbus, Archilochus, and Aceros. In his discussion of the Anomalogonatae (those birds lacking the ambiens muscle), Beddard (1898: 167) stated that but few possess the expansor secundariorum muscle (see page 137). He asserted that this muscle was absent in all families (present or absent in the Caprimulgidae and "appears to be absent" in the grebes) represented by the 6 genera listed above (Beddard, 1898: 168 and 387). Too little data are available to permit a positive statement, but it is possible that the origin of the expansor secundariorum muscle is limited to the distal end of the humerus and/or the humero-ulnar pulley in those birds lacking the ambiens muscle. With respect to the expansor secundariorum muscle, therefore, the main difference between the passerines and certain non-passerines is that in the latter group, this muscle arises from the distal end of the humerus, whereas in the passerines, it arises primarily from the humeroulnar pulley (but, it may also arise directly from the humerus). On the other hand, I have been impressed by the apparent uniformity of development of this muscle in passerine birds and by the reduction in the amount of the belly which extends proximad into the metapatagium.

Much remains to be learned about the gross anatomy of the expansor secundariorum muscle. There are few detailed descriptions of it in specific genera. Most authors who have referred to this muscle at all have simply quoted or paraphrased Garrod's original statement. My own feeling is that M. expansor secundariorum probably is present in most birds, though the degree of development may vary considerably. Consequently, there is a need to investigate all families, including those in which Garrod (1876:199) did not find this muscle. We need also to know in what group or groups of birds there is a "transitional" stage of development of this 
muscle between the "ciconine" or "cuculine" configuration and that found in the Pico-Passerines.

Other problems need to be solved. The histology of feather development (Hosker, '36; Lillie, '42) and the relationships of dermal muscles to the bases of the feathers (Seuffert, 1862; Langley, '03) have been studied in great detail, but further information is needed. Hosker, for example, made no reference to the muscles and Langley did not describe the microscopic structure of the muscles, nor was he concerned with the striated muscles which attach to feathers. The emphasis in a reinvestigation, therefore, should be directed to the relationships of both smooth and striated muscles to each other. and to both the follicle and the calamus of the feathers.

\section{MICROSCOPIC ANATOMY}

The position and relationships of the structure under consideration in passerine birds suggested strongly that it was at least a vestige of $M$. expansor secundariorum. It is small and usually is paler in color than the other wing muscles. Though the comparative histological study is still in progress and will be reported elsewhere, certain details are pertinent here. In brief, the following questions need answers: Is this a muscle or is it entirely ligamentous? If muscle fibers are present, what is their structure?

From the little information in literature on the expansor secundariorum muscle plus my own experience with it in several genera of birds, I first assumed that this muscle was composed of striated fibers. In the Sandhill Crane, for example, it seemed likely that such a relatively large muscle (10 $\mathrm{cm}$ in length), arising by a tendon from bones, was a striated muscle. It seemed quite possible, however, that in the Pico-Passeres this muscle might demonstrate a degenerate type of striated fiber or might be replaced by ligament. Phylogenetically, the muscle might be in the process of becoming vestigial.

In studying the material taken from passerine birds, the problem proved to be much more difficult, histologically, than 
anticipated. The fibers are very small (average diameter, $2.1 \mu$ in one series of fasciculi from Cyanocitta) and I was never sure that $I$ had isolated an individual fiber throughout its entire length. There seemed to be little doubt, however, that one was dealing with muscle, rather than with ligament (see fig. 5). It was not possible to demonstrate the presence of striations, nor do any of the slides exhibit any suggestion of atrophy or degeneration of the muscle fibers. All evidence obtained thus far indicates that the expansor secundariorum muscle in passerine birds is composed of functional smooth muscle fibers.

The question then arose whether this muscle in passerine birds is homologous with the large muscle, of an entirely different origin, found in the Sandhill Crane and certain other non-passerines. The microscopic study showed that, indeed, this muscle in the crane also is composed of smooth muscle fibers (this in itself, of course, does not prove homology). The presence of a uniform mass of smooth muscle $10 \mathrm{~cm}$ long was an unexpected finding. The fact that such a smooth muscle arises by a long tendon attached to bony elements may be a unique feature not found in other vertebrate classes.

In the Florida Gallinule, both parts (that arising from the humerus and that arising from the scapular tendon) of this muscle are composed of smooth muscle fibers. This fact may, in part, explain the origin of the expansor secundariorum muscle from the humero-ulnar pulley in the Passeriformes. The scapular tendon has disappeared in all genera of passerines investigated for this paper (it is possible that it might be found as an anomalous structure if a large series of a given genus was studied) and it is reasonable to assume that this tendon is not found of regular occurrence in any of the genera studied, and probably not in any passerine bird (with the possible exception of the Asiatic genera of Broadbills). Furthermore, the belly which arises from the scapular tendon (the "typical" expansor secundariorum) in many non-passerine birds has almost disappeared in the passerine birds. When a small, almost rudimentary, slip of muscle does extend 
proximad in the metapatagium, this slip is closely related to the tendon of M. serratus superficialis metapatagialis. I assume that the tendon of origin for the bulk of the belly of the expansor secundariorum muscle in passerine birds has migrated distad from the humerus to the humero-ulnar pulley.

I found further that in Colinus and Columba, as in Gallinula, both the "scapular" belly and the humeral belly of this muscle are composed of smooth muscle fibers. In Podilymbus, Archilochus, Aceros, and Colaptes, where the humeral belly only is present, it is a smooth muscle.

In Columba and Grus, however, the fleshy belly which arises from the scapular tendon and which inserts with the triceps tendon (see pages 144 and 159) is composed of striated fibers.

Again, in the Roadrunner the belly arising from the scapular tendon is composed of smooth muscle fibers. What appears grossly to be the single humeral tendon of origin gives rise primarily to striated fibers (average diameter of one series, $29.1 \mu$ ), but the most proximal fasciculi arising from this "tendon" are composed of smooth muscle fibers (fig. 9). With a binocular microscope, however, one can demonstrate that there are actually two bellies involved, though the tendons of origin seem to have fused. The larger, striated belly tends to overlap part of the smaller smooth muscle belly, and there is a continuous area of insertion on the proximal secondaries. The smooth muscle fibers I consider to be a part of M: expansor secundariorum; the striated fibers probably are derived from M. flexor carpi ulnaris. The smooth muscle fasciculi are invested by a greater amount of connective tissue than are the striated fasciculi. This muscle complex in Morococcyx is similar to that in Geococcyx. In Crotophaga, on the other hand, the single, roughly $V$-shaped belly has two tendons of origin, one from the humerus, the other from the scapula (Berger, '54: 17 and fig. 1). This muscle is composed of smooth muscle fibers, and it is separate and distinct throughout from the special striated slips of M. flexor carpi ulnaris, which arise from the humero-ulnar pulley and which insert on the bases of several of the secondaries (Berger, '54: 22 
and fig. 1). This latter specialization of M. flexor carpi ulnaris is characteristic of many cuckoos and of Jynx and Colius (Buri, '00:543), but is not found in all birds.

One can summarize by stating that the typical expansor secundariorum muscle, as described by Garrod, is composed of smooth muscle fibers.

Two other "dermal" muscles are, in some birds, either directly or indirectly associated with the expansor secundariorum: serratus superficialis metapatagialis (see page 147) and latissimus dorsi metapatagialis. In the genera examined microscopically (Podilymbus, Gallinula, Geococcyx, Passer, Sturnella), both muscles are composed of striated fibers. I did not examine the other dermal muscles (for a list of these, see Shufeldt, 1890: 3 and 93), but it seems likely that all except $M$. expansor secundariorum are composed of striated fibers. This muscle, therefore, may be unique among the dermal muscles of birds, as well as in other vertebrate classes. A thorough reinvestigation of the avian dermal muscles is indicated.

\section{DISCUSSION}

Few European and only 4 American writers (Burt, '30; Berger, '53, '54, '55; Hudson and Lanzillotti, '55) have dealt with M. expansor secundariorum. In discussing the gross anatomy of this muscle, I presented the general concept of it first proposed by Garrod (1876: 193-194). It now is necessary to introduce the ideas of Max Fürbringer, whose ideas apparently were not adopted by later workers. I have not found any critical discussion on the subject in Gadow and Selenka (1891) or in Beddard (1898).

Fürbringer (1886: 124; 1888: 708 and pl. 26; '02: 571) thought that the belly of Garrod's M. expansor secundariorum was a dermal muscle, composed of smooth muscle fibers. The long tendon (first mentioned by Carus, 1826, 1827: 359) arising in the axillary region, he considered a part of M. triceps brachii; this part he called "Caput coracoideum $\mathrm{m}$. anconaei." In the distal onc-fifth to two-fifths of the arm in 
some birds, this tendon gives origin to a fleshy belly composed of striated fibers, M. anconaeus coracoideus (first described by Fürbringer); this muscle shows its best development in Pelecanus (Fürbringer, '02: 576 and fig. 255); it inserts by a fine tendon on the proximal end of the ulna next to the tendon of M. humerotriceps (= "M. anconaeus humeralis"). Fürbringer further stated that this muscle belly is "completely vestigial" in the majority of birds (1886: 124 ), but that often the tendon is retained. Later ('02:575) he said that this tendon widens distally and serves as an area of origin for the smooth musculature of M. expansor secundariorum "which is completely heterogeneous to the tendon and originally is not related to it." Thus, as a result of his study of the myology of reptiles and birds, Fürbringer believed that the belly of M. anconaeus coracoideus had disappeared in most birds and that there had occurred a secondary fusion between its tendon and the belly of M. expansor secundariorum.

Though he gave no details in his discussion of "Tendo $\mathrm{m}$. anconaei coracoidei,' Fürbringer ('02: 572) stated that this tendon is absent in "most Passeres." Gadow and Selenka (1891: $260 ; 1893: 261$ ) stated that M. expansor secundariorum is absent in the Pici and the Passeres, but they also stated (1893: 275) that the "tendo anconaei coracoidei was still not completely reduced" in the family Eurylaimidae (which, at that time, did not include the two African genera mentioned in this paper).

Beddard (1898: 85), apparently influenced by Fürbringer (1888: 708), said that M. expansor secundariorum "appears to be partly a skin and partly a skeletal muscle. A bundle of non-striated fibres arises near the secondary feathers of the arm and ends in a tendon. This is occasionally reinforced by a band of striated fibres arising from beginning of ulna." He adds (1898: 405) that this muscle is unstriated in Sula, but is striated in Pelecanus. Obviously, two different muscles are involved here. 
Gadow and Selenka (1891: 260-261) quoted Fürbringer's statement (1886: 124), but did not comment on it. On the other hand, they considered M. expansor secundariorum to be a part of their M. metapatagialis, a complex, rather than a single muscle, composed also of M. serratus superficialis metapatagialis and M. latissimus dorsi metapatagialis. As pointed out above (page 154), the last two are striated muscles. M. metapatagialis, therefore, is not only a complex, it is not even composed of homogeneous elements. In their discussion of M. metapatagialis, Gadow and Selenka adopted Garrod's concept of the expansor secundariorum.

Consequently, what appeared at first to be a simple matter of determining the presence or absence of a muscle developed into a much more complicated problem. The thoroughness characterizing the studies of such men as Garrod, Fürbringer, and Gadow leads one inevitably to analyze their data and to give serious consideration to their conclusions. In the light of more recent information one can at times, however, interpret their data in a different way. I believe that we can discount the suggested homology of Fürbringer's "Caput. coracoideum m. anconaei" in reptiles and birds. Fürbringer's analysis of myology and neurology in reptiles and birds was, of course, influenced by his theory of nerve-muscle specificity, long one of the tenets of comparative anatomy. Though there is still a need for more investigation, Straus ('46: 89), in his review of the subject, commented that Fürbringer's theory - that there is an unvarying, specific relationship between particular macroscopic, peripheral nerve branches and particular muscles - "is founded upon a false embryological concept and is completely negated both by comparative and experimental data." $\mathrm{He}$ further stated that resemblance in muscular nerve supply " must merely reflect general similarity in development," so that innervation is of great aid in homologizing the muscles of animals belonging to one vertebrate class, but not in homologizing the muscles of animals of different classes. 
So little is known about the total myology of most families of birds that one hesitates to draw broad conclusions. What, then, can one say about the expansor secundariorum muscle? The presence of this muscle in passerine birds was apparently first reported by Buri ('00:545), who stated that it was composed of elastic fibers in the Hirundinidae (IIirundo rustica, Delichon ["Chelidonaria"] urbica, and Progne subis). He added ('00:375, 542, and 546) that M. expansor secundariorum is composed of smooth muscle fibers in non-passerine birds, though he may only have been quoting Fürbringer. Nevertheless, the data which I have obtained also indicate that this muscle is composed of smooth muscle fibers both in non-passerine and in passerine birds. In none of the sectioned or macerated material have I been able to demonstrate striations or other features characteristic of striated muscle. At the same time, all of the present evidence suggests that this muscle in passerine birds is composed of muscle fibers and not of elastic fibers. (Beddard, 1898, page 172, stated that the expansor secundariorum is not present in the Passeres, but in a tabulation on page 168 , he listed it as being rudimentary in that group; he gave no other information on this muscle in passerine birds.)

Hence, Fürbringer was correct in considering M. expansor sceundariorum to be a dermal muscle, composed of smooth muscle fibers. Data on this muscle from the many families of birds are insufficient to postulate the area of origin of this muscle in ancient birds. However, as implied by Fürbringer, the origin almost certainly was not through the medium of a long tendon attached to bones of the pectoral girdle.

Furthermore, it is obvious that a single musele cannot contain both smooth and striated fibers. The discovery that both smooth and striated fibers are present in the humeral belly of this "muscle" in Geococcyx and Morococcyx indicates only that there has been a partial fusion of two adjacent muscles having, in general, a common origin and a common insertion. Other instances are known of two different muscles fusing and having a common insertion (e.g., the biceps femoris 
in man), but the striking feature in the present instance is such a fusion involving both smooth and striated muscle.

The facts presented in this paper mean that in further studies of wing myology, it will be necessary not only to look for the expansor secundariorum muscle, but also to determine its microscopic structure. The name "expansor secundariorum" is well entrenched in ornithological literature and it is, furthermore, useful for describing this peculiar muscle. I see no reason, therefore, for changing the name, but it is necessary to understand just what the muscle is.

The expansor secundariorum muscle is composed of smooth muscle fibers and it inserts on two (Archilochus colubris) or more (three in many birds) of the proximal secondaries, and occasionally sends fasciculi to insert on distal tertials located near the elbow. The origin is far more variable. It arises almost exclusively from the humero-ulnar pulley in passerine birds, but there may also be a small proximallydirected slip, which is intimately associated with a fibrous or tendinous band of $\mathrm{M}$. serratus superficialis metapatagialis. In several genera of Picidae (see page 149), in Caprimulgus, Apus, and Colius (see Buri, '00), and in Podilymbus, Archilochus, and Aceros the muscle is similar, but the tendon arises from the distal end of the humerus, rather than from the humero-ulnar pulley.

In all non-passerine genera reported here, except for Podilymbus, Archilochus, Aceros, and Colaptes, the so-called "typical" origin for this muscle is by means of a long tendon attached primarily to the sternum and/or the scapula or (in Colinus) to $\mathrm{Mm}$. dorsalis scapulae and pectoralis - the origin of this tendon in gallinaceous birds is extremely variable (see Garrod, 1881: 324). In other genera (Grus, Gallinula, Columba), the main tendon has secondary attachments to M. dorsalis scapulae; Fürbringer ('02: 573) lists genera in which this tendon may also be attached to Mm. coracobrachialis posterior, subcoracoideus, or sternocoracoideus. In all non-passerine genera reported here there is also an origin from the distal end of the humerus. Until a detailed com- 
parative histological and neurological study is completed, there is no reason to belicve that the smooth muscle arising from the humero-ulnar pulley in passerine birds is not homologous to the similar belly arising from the distal end of the humerus in non-passerine birds.

The striated fibers arising from the distal end of the humerus (and from the humero-ulnar pulley) in Geococcyx, and which have secondarily appropriated for their insertion the bases of several of the proximal and central secondaries, are in all probability derivatives of M. flexor carpi ulnaris. Buri ('00: 543 and plates 20 and 21) came to the same conclusion with respect to this muscle in Jynx and Colius.

A musele, composed of striated fibers, arising from the long tendon attached to bones of the pectoral girdle and inserting either on the distal end of the belly of $M$. triceps brachii or on the proximal end of the ulna (e.g., as in Grus and Columba) is probably best considered to be an accessory or vestigial slip of the triceps muscle, and corresponds to Fürbringer's “'M. anconaeus coracoideus." Fürbringer ('02: figs. 255, 256, 257) illustrated the relationship of the latter muscle to M. expansor secundariorum in Pelecanus, Chauna, and Ciconia, and he discussed the relative development of this muscle in certain other genera ('02: 575-576).

\section{SUMMARY}

I believe that little reliance can be placed in most published statements asserting the absence of M. expansor secundariorum in various groups of birds. Many more genera, representing nearly all non-passerine as well as passerine families, need to be studied before a summary statement can be made on the absence or degree of development of this muscle in birds. The fact that all of the standard references ascribe, without adequate basis, taxonomic significance to this muscle makes it imperative that future investigators ascertain the true status of it in their particular groups.

The presence of this muscle in passerine birds was, apparently, first reported by Buri ('00), who stated that it was 
composed of elastic fibers in the Hirundinidae. Hudson and Lanzillotti ('55) next described this muscle in passerines (Corvidae) and stated that it "probably has limited power of contraction due to the fibrous connective tissue permeating its belly."

The expansor secundariorum muscle, first deseribed by Garrod (1876:193), is a dermal muscle, composed of smooth muscle fibers. I have found this muscle to be present in all genera of birds, both passerine and non-passerine, that I have dissected. In all genera, the muscle inserts on the calami of several of the proximal secondaries and, in some birds, also inserts on the distal tertials, located near the elbow. The number of secondaries on which this muscle inserts is, as far as is now known, not taxonomically significant.

In the Passeriformes, this muscle arises primarily from the humero-ulnar pulley. The belly frequently is related to extensions of the tendon of M. serratus superficialis metapatagialis. In Podilymbus, Caprimulgus, Apus, Colius, Archilochus, Aceros, and in all genera of the Picidae thus far investigated, the muscle arises from the distal end of the humerus.

All published accounts of the expansor secundariorum muscle in other non-passerine birds (excepting the family Cuculidae and the illustration by Hudson and Lanzillotti [' $55: 42$ ] of this muscle in Dendragapus obscurus) describe but one tendon of origin. This tendon ("Tendo m. anconaei coracoidei" of Fürbringer) has a wide variety of attachments, the most common of which are to the sternum and scapula and/or to one or more of the following muscles: dorsalis scapulae, coracobrachialis posterior, subcoracoideus, sternocoracoideus, and pectoralis.

In the following species, however, I found a second tendon of origin from the distal end of the humerus: Colinus virginianus, Polihierax semitorquatus, Grus canadensis, Gallinula chloropus, Columba livia, Coccyzus americanus, C. erythropthalamus, Crotophaga sulcirostris, Geococcyx californianus, Morococcyx erythropygus, Coua caerulea, Turacus donaldsoni. 
In a few birds, another muscle (Fürbringer's “M. anconaeus coracoideus"), composed of striated fibers, arises from the "scapular" tendon ("Tendo m. anconaei coracoidei") and inserts in common with the tendon of M. triceps brachii on the proximal end of the ulna. This muscle I found in Columba livia and Grus canadensis tabida. Fürbringer ('02) described and illustrated it in Pelecanus, Chauna, and Ciconia, in which genera it exhibits its best development.

Gadow's M. metapatagialis is a complex composed of two striated muscles (serratus superficialis metapatagialis and latissimus dorsi metapatagialis) and one non-striated muscle (expansor secundariorum).

The occurrence of relatively large, uniform masses of smooth muscle (e.g., $10 \mathrm{~cm}$ long in Grus) in many non-passerine birds may be of special interest to physiologists, pharmacologists, and other investigators concerned with function, reaction to drugs, and innervation of smooth muscle fibers.

\section{LITERATURE CLTED}

Bannerman, D. A. 1936 The birds of tropical West Africa. Vol. 4. Crown Agents for the Colonies, London, $459 \mathrm{pp}$.

BEDDARD, F. E. 1898 The structure and elassifieation of birds. Iongmans, Green \& Co., London, 548 pp.

Bensley, R. R., AND S. H. Bensley 1938 Handbook of histological and eytological technique. Univ. Chicago Press, Chicago, $162 \mathrm{pp}$.

Berger, A. J. 1953 On the locomotor anatomy of the Blue Coua, Coua caerulea. Auk, $\% 0: 49-83$.

1954 The myology of the pectoral appendage of thrce genera of American cuckoos. Mise. Publ. Mus. Zool. Univ. Mich., No. 85, pp. 1-35. 1955 On the anatomy and relationships of Glossy Cuckoos of the genera Chrysococeyx, Lampromorpla, and Chaleites. Proc. U. S. Natl. Mus,, Vol. 103, No. 3335: 585-597.

1956 The appendieular myology of the Pygmy Falcon (Polihierax semitorquatus). Ancr. Mi(ll. Nat., 55 : $326-333$.

Buri, R. O. 1900 Zur Anatomie des Flügels von Micropus melba und einigen anderen Coracornjthes, zugleich Beitrag zur Kemmis der Systematischen Stellung der Cypsclidae. Jena. Zeitschr. f. Naturwiss., 33: 361-610.

Bcrt, W. H. 1929 Pterylography of certain Nortl American woodpeckers. Univ. Calif. Publ. Zool., 30: 427-442.

1930 Adaptive rodifications in the woodpeckers. Unir. Calif. Publ. Zool., 32: 455-524. 
Carus, C. G. 1826 Erläuterungstafeln zur vergleichenden Anatomie. Heft 1, Leipzig.

1827 An introduction to the comparative anatomy of animals. Translated by R. T. Gore. Vol, 1, 371 pp., plus Atlas with 20 Copper pls. Longman, Rees, Orme, Brown, and Green, London.

Forbes, W. A. 1885 The collected seientific papers of the late William Alexander Forbes. Ed. by F. E. Beddard. London.

F̈̈rbringer, M. 1886 Über Deutung und Nomenklatur der Muskulatur des Vogelflügels. Morph. Jahrb., 11: 121-125.

1888 Untersuchungen zur Morphologie und Systematik der Vögel, zugleich ein Beitrag zur Anatomic der Stütz- und Bewegungsorgane. 2 vols. Amsterdan : van Holkema, $1751 \mathrm{pp}$.

1902 Zur Vergleichenden Anatomie des Brustschulterapparates und der Schultermuskeln. Jena. Zeitsehr. f. Naturwiss., 36: $289-736$.

Gadow, H., ANd E. Serrinka 1891-1893 Aves. In: Bronn's Klassen und Ordnungen des Thier-Reichs, in Wort und Bild. 2 vols. Anatomiseher Theil, 1891, 1008 pp. Systematischer Theil, 1893, 303 pp.

Garrod, A. H. 1876 On the anatomy of Chauna derbiana, and on the systematic position of the Screamers (Palamedeidae). Proe. Zool. Soc. London, pp. 189-200.

1881 The collected scientific papers of the late Alfred Henry Garrod. Ed. by W. A. Forbes. London

Helm, F. 1884 Ueber die Hautmuskeln der Vögel, ihre Beziehungen zu den Federfluren und ihre Functionen. Jour. f. Ornith., 32: 321-379.

HIosken, A. 1936 Studies on the epidermal struetures of birds. Philos. Trans. Royal Soe. London, Ser. B, Vol. 296 : 143-188.

Huber, G. C. 1916 On the form and arrangement in faseiculi of striated voluntary muscle fibers. Anat. Rec., 11: 149-168.

Hudson, G. E., and P. J. Lanzillote 1955 Gross anatomy of the wing museles in the family Corvidae. Amer. Midl. Nat., 53: 1-44.

LANGLEY, J. N. 1903 On the sympathetic system of birds and on the muscles which move the feathers. Jour. Physiol., 30: 221-252.

LEACF, J. A. 1914 The myology of the Bell-Magpie (Strepera) and its position in elassification. Emu, 14: 2-38.

LiLite, F. R. 1942 On the development of feathers. Biol. Reviews, 17: 247-266.

LILlIE, R. D. 1948 Histopathologic technie. Blakiston Co., Philadelphia, 300 pp.

Lowk, P. R. 1924 On the presence of Broadbills (Eurylaemidae) in Africa. Proc. Zool. Soc. London, 1924: 279-291.

1931 On the anatomy of Pseudocalyptomena and the occurrence of Broadbills (Eurylaemidae) in Africa. Proc. Zool. Soc. London, 1931: 445-461.

NewToN, A. 1896 A dietionary of birds. Adam and Charles Black, London, $1088 \mathrm{pp}$.

Pycrafr, W. P. 1905 Contributions to the osteology of birds. Part VII. Eury. laemidae; with remarks on the systematic position of the group. Proc. Zool. Soc. London, 1905, 2: 30-56.

Ridaway, R. 1901 The birds of North and Middle America. U. S. Natl. Mus. Bull. 50, pt. 1 . 
SEUFFERT, L. 1862 Ueber das Vorkommen und Verhalten glatter Muskeln in der Haut der Säugethiere und Vögel. Würzburger Naturwiss. Zeitschr., 3: 111-158.

SHUFELDT, R. 1890 The myology of the Raven (Corvus corax sinuatus). Macmillan Co., London, $343 \mathrm{pp}$.

Straus, W. L., JR. 1946 The concept of nerve-musele specificity. Biol. Reviews, 21: $75-91$.

SWINEBROAD, J. 1954 A comparative study of the wing myology of certain passerines. Amer. Midl. Nat., 51: 488-514.

Witherby, H. F., F. C. R. Jourdain, N. F. Ticehurst and B. W. Tucker 1943 The handbook of British birds. Vol. 1. H. F. \& G. Witherby Ltd., London, 326 pp. 
PLATE 1

FEPLANATION OF FIGURES

4 Partially teased smooth muscle fibers of $\mathrm{M}$. expansor secundariorum. Columba livia. Hematoxylin. $\times 790$.

5 Partially teased smooth musele fibers of $\mathrm{M}$. expansor secundariorum. Bombycilla cedrorum. Hematoxylin. $\times 790$.

6 Partially teased smooth muscle fibers from intestinal wall of Dendroica pinus. Hematoxylin. $\times 790$.

7 Longitudinal section of feather showing insertion of M. expansor secundario rum in Cyanocitta cristata. Masson. $\times 46$. 

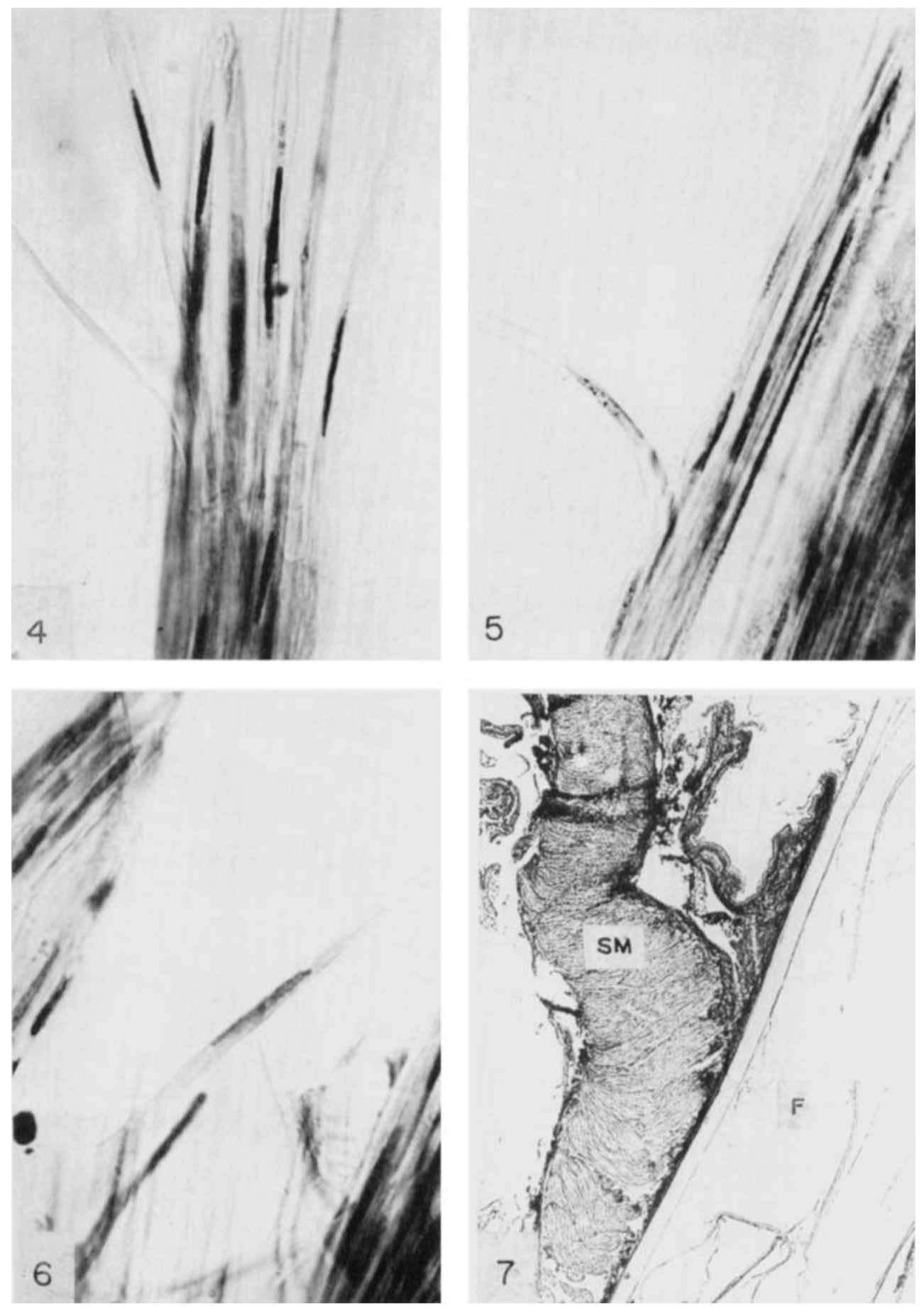


\section{PIATE 2}

\section{EXPLANATION OF FIGURES}

8 Section of elbow region of Geococyx californianus showing origin of M. expansor secundariorum from humerus and its insertion on feathers. Hematoxylin and eosin. $\times 22$.

9 Section showing both smooth muscle and skeletal muscle inserting on feathers. Geococcyx californianus. Hematoxylin and eosin. $\times 46$. 

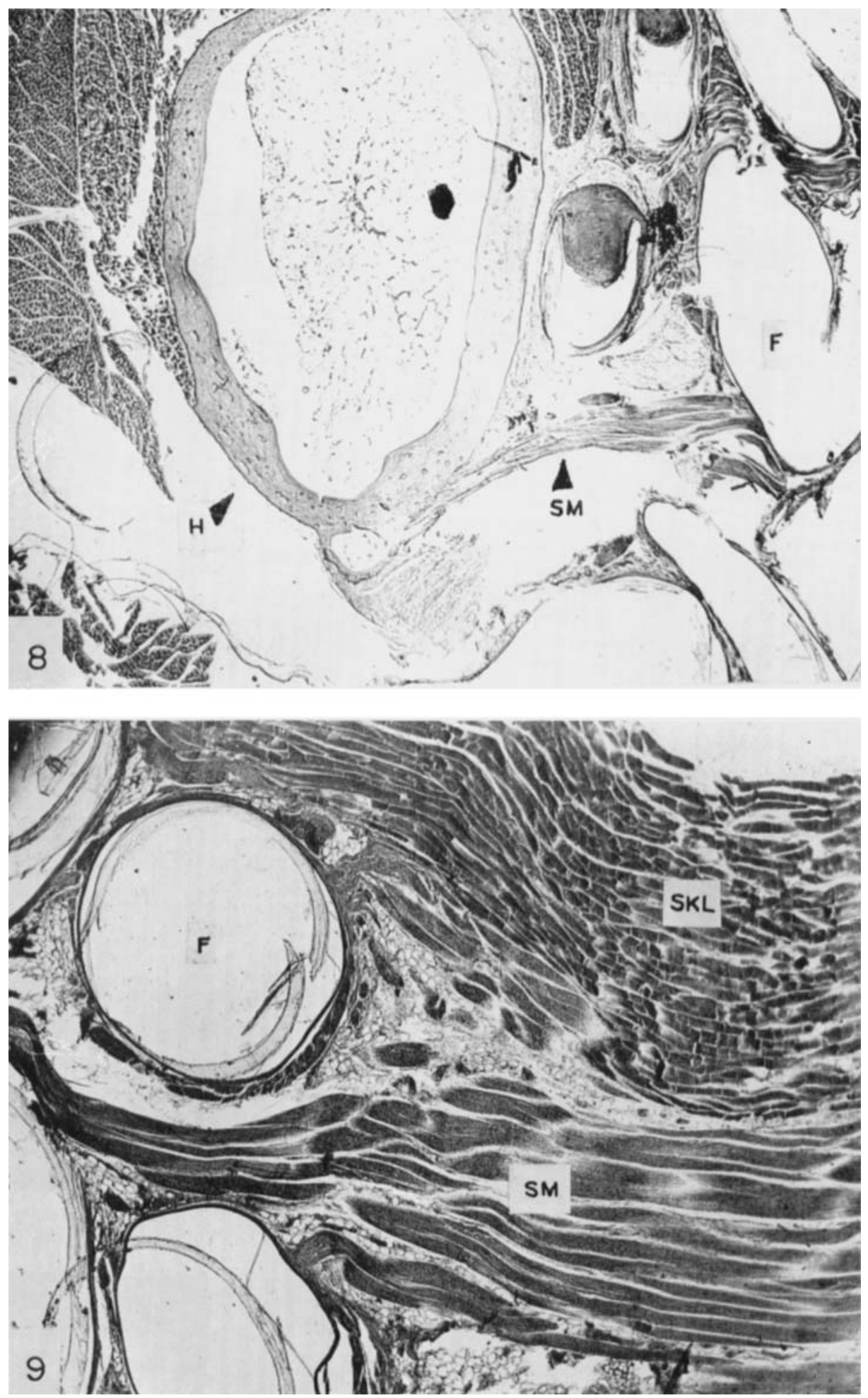